\title{
Modern Methods of Bioengineering in Production of Probiotics
}

\author{
Murat Zh Nurushev ${ }^{1 *}$ and Lidia Gr Stoyanova ${ }^{2}$ \\ ${ }^{1}$ L.N. Gumilyov Eurasian National University, Astana, Kazakhstan \\ ${ }^{2}$ M.V. Lomonosov Moscow State University, Moscow, Russia
}

Submission: February 03, 2017; Published: June 27, 2017

"Corresponding author: Murat Zh Nurushev, L.N. Gumilyov Eurasian National University, Astana, Kazakhstan, Email: nuryshev@mail.ru

\begin{abstract}
Physiological and biochemical features of new strains were studied and compared to the nisin-producing strain Lactococcus lactis ssp. lactis MSU. According to morphological, cultural, physiological, biochemical properties and gene sequence of 16S rRNA a novel most effective strain 194 was identified as Lactococcus lactis ssp. lactis (GenBank database DQ 255954), absolutely harmless for human health and animals. We studied the probiotic properties, sensitivity to antibiotics and show the therapeutic effect of strain as a food additive on model mice CBRB-Rb 1Iem chronic dermatitis. Thus, the properties of the strain 194, such as wide spectrum action to the pathogenic species and medical effect in a mouse model of chronic dermatitis enable to recommend the strain L. lactis ssp. lactis 194 for using as probiotic culture.
\end{abstract}

Keywords: Probiotic; Culture; Lactococcus lactis subsp. Lactis; Identification; Bacteriocin; Sensitivity to Antibiotics

\section{Introduction}

Probiotics are live microorganisms, which refer to a normal inhabitant of the intestines of healthy animals and human [1]. But to define probiotic properties, microbes should be considered with the ability to provide immunomodulatory impact and allocate metabolites which stimulate the development of normal microbiocenosis $[2,3]$. The largest group of probiotic bacteria in the intestine is lactic acid bacteria (LAB). The genus Lactococcus has "GRAS"-status (absolutely harmless for human health and animals) accordingly to the European Commission [4], while the member of genera Streptococcus and Enterococcus contain some opportunistic pathogens. Bacteriocins differ from each other by chemical structure and antagonistic activity. Lactococcus lactis produces bacteriocins as lacticins 48, 3147, several forms of nisin and lactococcins [1,5]. Nisin is a unique, nontoxic antibiotic. Nisin is the best studied compound in the latter group. It is the only antibiotic substance given the status "GRAS", which is allowed for application as food preservative under the code E234. Nisin is the low-molecular mass protein so it is easy to apart it into amino acids during digestion and does not influence microbiota of gastrointestinal tract [6,7]. One of the very important properties of nisin is the activity against Gram-positive bacteria and bacterial spores of clostridia and bacilli, other non-spore forming bacteria, as many species of pathogenic Streptococci, Staphylococci, Listeria, Mycobacterium tuberculosis, but it is not effective against Gramnegative enterobacteria and fungi $[5,8]$.
Fungal spoilage of food is a common and global phenomenon. The potential production of toxins by fungi is of particular health concern. As mentioned above, Lactococcus spp. strains generally inhibit only Gram-positive bacteria and they are not effective against fungi. But recently it was revealed that some lactococci strains have an ability to produce antifungal substances which were determined as peptide and lowmolecular phosphoglycolipid [9]. For this reason lactococci can be considered as potential producers of different antimicrobials with wider activity spectrum than nisin. In fact, two antibiotics, nisin and lacticin 3147, have been found useful in preventing dyskinesia, mastitis, dermatitis, type impetigo, ecthyma, scalded skin syndrome forms of chronic dermatitis in humans [6,10-12].

At present, the ways of targeted synthesis of antimicrobial substances by lactococci are studied in order to obtain new ones with more valuable properties for application them as probiotics. The interest in the use of bacteriocin producer cultures as probiotics has increased tremendously. Screening of effective strains from raw milk products from Buryatia-North Asiatic region of Lake Baikal, with wide variety of climatic and ecological niches, which creates conditions for a variety of LAB and their unique properties are of great scientific and practical interest.

The aim of this investigation was to isolate and identify the new lactococci strains from Buryatia with bactericidal 
and fungicidal activity and study of their probiotic properties. Scientific work «Design and creation of a new natural food preservative on the basis of bacteriocins of lactic acid bacteria with GRAS status» were carried out within the grant project of the Ministry of Education and Science of the Republic of Kazakhstan. Researches were conducted together with scientists of Lomonosov Moscow State University on the basis of Laboratories of department of microbiology of biological faculty in 2012-2015.

\section{Materials and Methods}

Media and conditions of isolaton of natural lactococci strains Raw cow's milk obtained from the milk farm of Buryatia (Russia) was used in the work. The tubes with investigated milk were left for spontaneous self-fermentation at $28^{\circ} \mathrm{C}$ in steadystate conditions for $17 \mathrm{~h}$. Then bacteria from the tubes, where a dense milk clot formed, were subjected upon several passages in skimmed milk over $10-17 \mathrm{~h}$. These conditions are allowed to propagate the homo-fermentative lactococci, which then were inoculated into the agar milk hydrolysate with bromocresol purple indicator. The individual acid-producing colonies from the surface of the agar medium were transferred onto the lawn with the test culture for nisin determination activityBacilluscoagulans 429, a thermophilic spore-forming, acidresistant bacterium, using a sterile replicator and, in parallel, to the same solid medium without test culture. The clones forming the largest growth inhibition zones of test organism were selected as active nisin-producing strains. To obtain the lawn of the test culture, a $24 \mathrm{~h}$-old culture of $B$. coagulans, grown at $55^{\circ} \mathrm{C}$ on the agar organic medium (g/l): glucose: 10.0, peptone: 5.0 , $\mathrm{NaCl}$ : 5.0, agar: 20.0 with an addition of Hottinger's broth (at a concentration of $28 \mathrm{mg} \%$ according to ammonium nitrogen) at $\mathrm{pH}$ 7.0 was plated in Petri dishes. Cultural properties of the isolated strains were examined by classical microbiological methods of identification and determination of the culture $[13,14]$. The phylogenetic analysis using the sequences of the 16S rRNA genes was performed using the programs Vector NTI: Contig Express and AlignX. A comparative analysis and search for homologous sequences were performed using the NCBI database (ttp://www. ncbi.nlm.nih. gov/blast). Multiple alignments of the sequences were obtained by the program ClustalX; the alignments were constructed and the genetic distances between the strains compared were computed by the program Mega.

The strains were compared according to their cultural, physiological, and biochemical properties. The physiological and biochemical properties of strains displaying the most pronounced antibiotic activity were assessed according to the fermentation of carbohydrates, the demand for growth factors, the level of inhibitory activity, and the range of antimicrobial action. We used the series of carbohydrates: D-arabinose, D-xylose, D-ribose, D-glucose, L-rhamnose, D-maltose, D-sucrose, D-mannose, D-lactose, D-galactose, raffinose, D-fructose, D-sorbitol, dulcitol, mannitol, dextrin, glycerol and starch, which were added to the base fermentation medium in amounts of $1.0 \%$ each. For growth factors DL-valine, DL-threonine, DL-leucine, L-serine, L-lysine, DL-cystine, L-glutamate, L-aspartate, L-isoleucine, L-methionine, and L-cysteine were used. Each amino acid was introduced into the base fermentation medium in the amount of $0.01 \%$.

To obtain an inoculum, the culture from skimmed milk was reinoculated into the inoculation medium, which contained $1 \%$ glucose, yeast autolysate (35mg\% of ammonium nitrogen), and tap water ( $\mathrm{pH}$ 6.8-7.0). The culture was grown under steadystate condition at $28{ }^{\circ} \mathrm{C}$. Thereafter, the inoculum (OD540 0.14-0.19) was introduced in an amount of 5 vol.\% into the base fermentation medium, which contained (g/l): KH2PO4: 20.0; glucose: 10.0; $\mathrm{NaCl}: 1.0 ; \mathrm{MgSO}_{4}: 0.2$ and yeast autolysate (35mg\% ammonium nitrogen), $\mathrm{pH}$ 6.8-7.0 and culture was allow to grow at $28{ }^{\circ} \mathrm{C}$.

\section{The identification of the isolated strains and antimicrobial testing}

Probiotics, according to determination of the World Health Organization (WHO)-the microorganisms, useful to the person, having activity concerning pathogenic microorganisms both providing normal functioning of a microbiota of digestive tract and supporting an organism other functions. Pro-biotic microorganisms can be included in structure of various foodstuff, medicines and nutritional supplements.

The lactobacilli received from natural dairy products attracted particular interest of microbiologists in comparison with other pro-biotic bacteria. The advantage of these bacteria for health of the person is known since Hippocrates's times (the 4 th century BC), on their revitalizing effect-as means of fight against a premature old age-were specified by the academician Mechnikov [15]. Feature of lactococci is their capability to synthesize biologically active peptides or proteinaceous complexes known as bakteriotsina. One of the most known bakteriotsin-the antibiotic of lowlands allowed for use as food preservative under the E234 code. The antimicrobial activity of lactic acid bacteria was determined by the diffusion into agar by measuring of the growth inhibition zone of test cultures in $\mathrm{mm}$ [14]. The spectrum of inhibitory effects of the strains was studied by culturing strains under steady-state conditions in the fermentation medium of the above composition. The microorganisms used in these experiments were from the Collection of Microbes of the Department of Microbiology of Moscow State University: 6 strains of Gram-positive bacteria (Micrococcus luteus 128, Bacillus mycoides 32, B. subtilis 2, B. coagulans 429, B. cereus 112 and Staphylococcus aureus 144); 6 strains of Gram-negative bacteria (Alcaligenes faecalis 82, Escherichia coli 52, Proteus vulgaris 206, Pseudomonas aeruginosa 54, Salmonella gallinarum); 3 strains of fungi (Fusarium oxysporum 61, Penicillium chrysogenum 37, Aspergillus niger 369); and two yeast strains (Candida guilliermondii 17 and Rhodotorula aurantiaca 226). 
The bacilli were grown on an organic medium containing (g/l): glucose: 10.0, peptone: 5.0, $\mathrm{NaCl}: 5.0$ and agar: 25.0; the medium was supplemented by Hottinger's broth $(25 \mathrm{mg} \%$ amine nitrogen) and had a $\mathrm{pH}$ of 7.0. The yeasts were grown in a wort (6-8oB) medium supplemented with $2.5 \%$ agar $(\mathrm{pH}$ 6.8). The medium for the fungi was similar (wort $3-4 \mathrm{oB}$ with $2.0 \%$ agar; $\mathrm{pH}$ 6.0). The bacteria were cultured at $28-:-55^{\circ} \mathrm{C}$ : the temperature used in the case of bacilli, staphylococci, and micrococci was 37 ${ }^{\circ} \mathrm{C}$; E. coli was grown at $42^{\circ} \mathrm{C}$; B. coagulans at $55^{\circ} \mathrm{C}$, and yeasts and fungi, at $28^{\circ} \mathrm{C}$. Petri dishes were inoculated with 1-day cultures of test microorganisms $(0.1 \mathrm{ml}$ cell suspension in physiological saline per dish; the concentrations were adjusted to 109 cells per $1 \mathrm{ml}$ using a bacterial turbidity standard). The bacteriocinsynthesizing activity was assessed as nisin production judged by the suppression of growth of the indicator culture B. coagulans, which $\mathrm{s}$ was introduced into the agar medium as a suspension with a density of 109 cell/ml. Antibiotic substances were extracted from the cells and culture liquid using a 4:1:5 mixture of acetone, acetic acid, and water $\left(55^{\circ} \mathrm{C}, 1.5 \mathrm{~h}\right)$.

Quantitative determination of the antimicrobial activity was performed by measuring the zones of growth suppression with Quantitative determination of the antimicrobial activity was performed by measuring the zones of growth suppression with subsequent calculation involving a calibration plot for standard nisin solutions. Solutions of the preparations served as the standards: "Nisaplin" (activity 1000000 IU/g, "Aplin \& Barrett, Ltd" Co., UK) - for Gram-positives; chloramphenicol (HiMedia Laboratories Ltd, Mumbai)-for Gram-negative bacteria; nystatin (4670 U/mg, Sigma)-for fungi. The fungicidal activity was assessed with indicator culture Aspergillus niger 369 [14]. Physiological and biochemical features of new strains were studied Quantitative determination of the antimicrobial activity was performed by measuring the zones of growth suppression with subsequent calculation involving a calibration plot for standard nisin solutions. Solutions of the preparations served as the standards [14].

Physiological and biochemical features of new strains were studied and compared to the nisin-producing strain Lactococcus lactis ssp. lactis MSU. This strain was a reference strain which produces nisin A identical to that contained in the commercial preparation Nisaplin (Aplin \& Barrett Ltd., UK).The strain MSU was stored as lyophilized in a household refrigerator at $4{ }^{\circ} \mathrm{C}$. The lyophilized culture was reconstituted by sterile non-fat (skimmed) milk.

The dynamics of growth and bacteriocin accumulation in the culture liquid of strains were followed for $24 \mathrm{~h}$. The amount of the biomass was determined by optical density $(540 \mathrm{~nm})$. The sensitivity experiments to the antibiotics: ampicillin, erythromycin, tetracycline, lincomycin, kanamycin, streptomycin, rifampicin, neomycin and oleandomycin was performed by disk diffusion method.

\section{Testing the Lactococcus lactis ssp. lactis strain 194 as probiotic}

In our experiments the isolated lactococci were studied as probiotic cultures. It was conducted in model experiments of the effects of adverse conditions of the gastrointestinal tract by the action of high concentrations of bile acids (0-50\%) and hydrochloric acid (0 to $1.0 \%$ ), added to fermentative medium, on the viability of strains during the incubation for $1-3 \mathrm{~h}$. We checked the effect of culture of novel strain 194 on the symptoms of dermatoses on male mice CBRB-Rb (8.17) 1Iem at the age of $23,0 \pm 1,3$ weeks, as an adequate model of spontaneous chronic skin dermatitis, type impetigo, ecthyma and scalded skin syndrome. Animals were fed by complete pelleted feed. As a standard feed used cereal grains ( $5 \mathrm{~g}$ per mouse per day) with the addition of sunflower oil and vitamins A, E, D, F; water was unrestricted. Males mice of the experimental group $(n=17)$ were added daily for two weeks with the culture of Lactococcus in feed by 194 to $300 \mathrm{mkl}$ per mouse per day. Assessment of symptoms of dermatitis conducted a double-blind study once a week in all mice individually.

The following information was recorded:

i. The degree of ulceration or manifestation of alopecia of the skin on their backs by the 7-point scale;

ii. The area of the affected area of the back, in $\mathrm{mm}^{2}$;

iii. Weight gain. The experiment comprised three series of triplicate measurements each and the results were statistically processed.

\section{Results and Discussion}

\section{Screening for the strains and their isolation}

Screening for the effective bacteriocins-synthesizing strains of Lactococcus lactis was performed. Lactococci were isolated from raw milk from Ulan-Ude city area (Buryatia, Russia). The lactococcal colonies were selected in the media with the indicator bromocresol purple, which changed the color of the medium from violet to yellow indicating the acidification degree. It is known that the major product of homolactic acid fermentation is lactic acid. Overall, 18 colonies of mesophilic acid-producing bacteria were selected from which 5 isolated colonies inhibited the growth of test-microorganism B. coagulans, 2 of them displayed the highestactivity. The best strain named 194 was chosen for further study. The morphology and cultural properties of it were compared to the nisinproducing strain Lactococcus lactis ssp. lactis MSU. The morphology of the isolated strains demonstrated that the cultures were represented by cocci assembled in pairs or short chains of various lengths: two, four or 12 cells.

The bacteria were non-motile and Gram-positive. They did not differ in their cultural features from the bacteria belonging to the genus Lactococcus (Table 1). Growth was absent in the meat-peptone broth containing $6.5 \% \mathrm{NaCl}$ and at $\mathrm{pH}$ 9.6. The 
pH from 6.6 to 7.2 was optimal for the growth and development of these strains. The optimal incubation temperature was $28^{\circ} \mathrm{C}$; at $10{ }^{\circ} \mathrm{C}$ the growth was minimal and was completely absent at $45{ }^{\circ} \mathrm{C}$. Uniform growth of bacteria along the entire inoculum's length in a stab of an agar medium is characteristic of facultative anaerobes [11].

Table 1: Differentiating features of isolated lactococcal strains

\begin{tabular}{|c|c|c|c|c|c|c|}
\hline Properties & $\begin{array}{c}\text { L. } \\
\text { lactis } \\
\text { subsp. } \\
\text { lactis* }\end{array}$ & $\begin{array}{c}\text { Strain } \\
\text { MSU }\end{array}$ & $\begin{array}{c}\text { Strain } \\
194\end{array}$ & $\begin{array}{c}\text { Strain } \\
105\end{array}$ & $\begin{array}{c}\text { Strain } \\
122\end{array}$ & $\begin{array}{c}\text { Strain } \\
205\end{array}$ \\
\hline $\begin{array}{l}\text { The } \\
\text { preferential } \\
\text { location of the } \\
\text { most typical } \\
\text { cells }\end{array}$ & $\begin{array}{l}\text { short } \\
\text { chains }\end{array}$ & $\begin{array}{l}\text { Chains } \\
\text { (to 4-7 } \\
\text { cocci) }\end{array}$ & $\begin{array}{l}\text { diplo- } \\
\text { cocci } \\
\text { and } \\
\text { long } \\
\text { chains }\end{array}$ & $\begin{array}{l}\text { chains } \\
\text { to } 7 \\
\text { cocci }\end{array}$ & $\begin{array}{c}\text { diplo- } \\
\text { cocci }\end{array}$ & $\begin{array}{l}\text { chains } \\
\text { to } 7 \\
\text { cocci }\end{array}$ \\
\hline Mobility & - & - & - & - & - & - \\
\hline $\begin{array}{c}\text { Growth at } \\
10^{\circ} \mathrm{C}\end{array}$ & + & + & + & + & + & + \\
\hline $\begin{array}{c}\text { Growth at } \\
45^{\circ} \mathrm{C}\end{array}$ & - & - & - & - & - & - \\
\hline pH 9,6 & - & - & - & - & - & - \\
\hline $\begin{array}{c}\text { Growth in the } \\
\text { presence of } \\
4 \% \mathrm{NaCl}\end{array}$ & + & + & + & + & + & + \\
\hline $\begin{array}{c}\text { Growth in the } \\
\text { presence of } \\
6,5 \% \mathrm{NaCl}\end{array}$ & - & - & - & - & - & - \\
\hline To oxygen & \multicolumn{6}{|c|}{ facultative anaerobes } \\
\hline \multicolumn{7}{|c|}{ The ability to consume carbohydrates } \\
\hline Fructose & + & + & + & + & + & + \\
\hline Lactose & + & + & + & + & + & + \\
\hline Mannitol & - & - & - & - & - & + \\
\hline Sucrose & + & + & + & + & + & + \\
\hline Maltose & + & + & + & + & + & + \\
\hline Raffinose & - & - & - & - & - & - \\
\hline Starch & - & - & - & - & - & - \\
\hline
\end{tabular}

${ }^{*}$ Note - (negative)+(positive)

\section{Biochemical testing of isolates}

Ability to consume of various carbohydrates, including sugars, alcohols and organic acids is the basis of the distinguishing features in the identification of lactic acid bacteria. Studies have found that all strains utilized glucose, sucrose, lactose, galactose, maltose, mannose, fructose, and did not utilize-rhamnose, the trisaccharide raffinose and did not hydrolyze starch Strain 194 utilize not only arabinose and xylose, but also the alcohols: dulcitol, mannitol and sorbitol. The hallmark of lactic acid bacteria is a great need for complex nutrients: purines, pyrimidines, amino acids and vitamins, especially of group B. Amino acids are essential for the construction of the cell and for the bacteriocin formation. It is known that threonine, serine, cysteine, lysine, and aspartic acid are precursors of lanthionine and methyl-lanthionine and part of the nisin molecules [5].

The results of an experiment to determine the needs of strains in amino acids and other growth components revealed some features of the isolates (Table 2). Strain 194 showed good growth in media, indicating the specific needs in glutamine, asparagine, uracil, aspartic acid and arginine. Strain 122 does not require adenine and phenylalanine, as strain 105 did not require methionine, threonine, and diaminopimelic acid. Strain 205 did not need the following growth components: was detected in the media, which included histidine, glutamine, pyridoxine, isoleucine, uracil, biotin, valine, arginine, alanine. In medium containing glutamine, asparagine, uracil, aspartic acid, arginine, and which is a blend of vitamins to the amino acid alanine, grew all strains, indicating their need for uracil, arginine and vitamins. Studied lactococci grew equally well in media containing a mixture of amino acids in combination with vitamin B1 and biotin, as well as with uracil. In control experiments in the absence of growth factors in the environment lactococci did not grow, confirming that they belong to auxotrophic icroorganisms. Strains 194 and MSU need the presence of glycine in the medium. The absence of a serine or glycine had no effect on the growth of strains, except strain 194. Strain 105 has a very limited need for growth components, but proline and uracil stimulated its growth. All strains were in need of arginine.

Table 2: The need for growth components of isolated strains lactococci

\begin{tabular}{|c|c|c|c|c|c|}
\hline $\begin{array}{c}\text { Growth } \\
\text { Strain }\end{array}$ & $\begin{array}{c}\text { Strain } \\
\mathbf{1 9 4}\end{array}$ & $\begin{array}{c}\text { Strain } \\
\mathbf{1 0 5}\end{array}$ & $\begin{array}{c}\text { Strain } \\
\mathbf{1 2 2}\end{array}$ & $\begin{array}{c}\text { Strain } \\
\mathbf{2 0 5}\end{array}$ & $\begin{array}{c}\text { Strain } \\
\text { MSU }\end{array}$ \\
\hline Alanine & + & - & + & + & - \\
\hline Arginine & + & + & + & + & + \\
\hline Asparagine & + & + & - & + & - \\
\hline Aspartic acid & + & + & + & + & + \\
\hline Valine & - & - & + & - & + \\
\hline Glycine & + & - & - & - & + \\
\hline Glutamine & + & - & - & + & + \\
\hline Glutamine & - & + & - & - & + \\
\hline Thymine & + & - & + & + & - \\
\hline Uracil & + & + & + & + & + \\
\hline
\end{tabular}

*Note - (negative) $+($ positive $)$

\section{Taxonomic description of isolates}

To confirm the taxonomic status were conducted molecular genetic studies. Computer rocessing of the results of 16S rRNA gene sequencing and comparative analysis of our data with the sequences of the type strains revealed high similarity between them. Based on the phylogenetic distance, reflecting the differences between strains in the number of nucleotide substitutions per 100 base pairs (bp), 16S rRNA homology genes were calculated. All strains show a high degree of DNA homology 98.9-100\%) relative to the reference strain of L. lactis subsp. 


\section{Current Trends in Biomedical Engineering \& Biosciencess}

lactis. The level of genetic similarity (in \%\%) of all the strains studied in relation to closely related strains L. lactis subsp. cremoris was $95.4-96.6 \%$. The nucleotide sequences of the $16 \mathrm{~S}$ rRNA genes of novel strains were deposited to the GenBank database under following accession numbers: DQ255952-strain MGU and DQ255954-strain 194.

\section{Antimicrobial activity testing}

Only four of the selected strains expressed a broad spectrum of activity against pathogens: Listeria monocytogenes, Staphylococcus aureus, Escherichia coli, Pseudomonas aeruginosa, Proteus vulgaris, Salmonella and fungi of Aspergillus, Fusarium,

Table 3: Antimicrobial action of isolated strains of Lactococcus lactis ssp. lactis and MSU in compared with «Nisaplin»

\begin{tabular}{|c|c|c|c|c|c|c|c|c|c|}
\hline \multirow{3}{*}{ Test } & & & & Strains & & & & & \\
\hline & 119 & 222 & 229 & 116 & 205 & 115 & 194 & мгу & Nisaplin $3000 \mathrm{IU} / \mathrm{ml}$ \\
\hline & \multicolumn{9}{|c|}{ Diameter of inhibition zone, $\mathrm{mm}$} \\
\hline Bacillus mycoides & 20,0 & 10,0 & 16,0 & 19,5 & 16,0 & 11,0 & 24,0 & 15,0 & 17,0 \\
\hline Bacillus subtilis & 12,0 & 10,0 & 15,0 & 22,0 & 20,0 & 11,0 & 24,0 & 16,0 & 18,0 \\
\hline Bacillus coagulans & 17,0 & 8,0 & 15,0 & 18,0 & 18,0 & 20,0 & 23,0 & 18,0 & 21,0 \\
\hline Bacillus cereus & 18,5 & 10,0 & 14,0 & 21,0 & 19,0 & 15,0 & 12,0 & 16,0 & 18,0 \\
\hline Micrococcus luteus & 21,5 & 13,0 & 20,0 & 22,5 & 16,5 & 21,5 & 19,0 & 19,0 & 25,0 \\
\hline Staphylococcus aureus & 16,0 & 0 & 16,0 & 20,0 & 17,0 & 17,0 & 16,0 & 12,0 & 15,0 \\
\hline Alcaligenes faecalis & 0 & 9,0 & 10,0 & 12,5 & 12,5 & 15,0 & 12,0 & 0 & 0 \\
\hline Escherichia coli & 0 & 11,0 & 0 & 15,0 & 14,0 & 19,0 & 12,0 & 0 & 0 \\
\hline Proteus vulgaris & 0 & 9,0 & 0 & 16,5 & 16,0 & 14,0 & 16,0 & 0 & 0 \\
\hline Pseudomonas aeruginosa & 0 & 0 & 0 & 16,5 & 15,5 & 12 & 12,0 & 0 & 0 \\
\hline Fusarium oxysporum & 0 & 0 & 0 & 16,5 & 10,0 & 12,0 & 10,0 & 0 & 0 \\
\hline Penicillium chryzogenum & 0 & 0 & 0 & 17,5 & 10,5 & 12,0 & 16,0 & 0 & 0 \\
\hline Aspergillus niger & 0 & 0 & 0 & 21,0 & 10,0 & 14,0 & 15,0 & 0 & 0 \\
\hline Rhodotorula aurantiaca & 0 & 0 & 0 & 19,5 & 10,0 & 13,0 & 14,0 & 0 & 0 \\
\hline Candida guellermondii & 0 & 0 & 0 & 11,0 & 12,0 & 10,0 & 16,0 & 0 & 0 \\
\hline
\end{tabular}

It has been revealed, that the strain 194 produced antibiotic complex which differed from nizin. The strain 194 had higher antimicrobial productivity, up $3600 \mathrm{IU} / \mathrm{ml}$ (with test-culture B. coagulans) as compared with strain MSU (2000IU/ml). The inhibition activity against Gram-negative bacteria consisted of $370 \mathrm{U} / \mathrm{ml}$ (was detected with chloramphenicol), and its antifungal activity (with nistatin as a standard and test-culture .A.niger) was $1700 \mathrm{u} / \mathrm{ml}$. The strain MSU did not inhibited the growth of Gram-negative bacteria and fungi. The results of our study of the spectra of antibiotic activity of culture liquids of the strains of L. lactis subsp. lactis, grown in the fermentation medium, are summarized in Table 3. The strain MSU suppressed the growth of Gram-positive bacilli and micrococci in a manner similar to that of nisin. The strain 194 exhibited the highest antibiotic activity and exerted broad-spectrum of antibacterial and fungicidal effects, which has not been reported. The differences in the spectrum of effects of the strains are known to be due to structural diversity of the bacteriocins synthesized.
Penicillium genera, as wellas against yeasts Rhodotorula aurantiaca and Candida guilliermondii. The results of our study of the spectra of antibiotic activity of culture liquids of the strains of L. lactis subsp. lactis, grown in the fermentation medium, are summarized in Table 3. The strain MSU suppressed the growth of Gram-positive bacilli and micrococci in a manner similar to that of nisin. The strain 194 exhibited the highest antibiotic activity and exerted broad-spectrum of antibacterial and fungicidal effects, which has not been reported so far for this specie. The strain 194 was more effective against Rhodotorula aurantiaca and Candida guilliermondii.

\section{In our experiments isolated lactococci were studied for its probiotic properties}

The food entering the stomach is exposed to the gastric juice. Pure gastric juice has hydrochloric acid concentration of about $0.3-0.5 \%$, this corresponds to a pH of 1 to 3 in the healthy stomach. It was revealed that addition of $0.2 \%$ of hydrochloric acid to the cultural medium the growth rates were reduced by $30 \%$ to $49 \%$ after 3 hours of incubation. But the strain is resistant to high concentrations of hydrochloric acid $(0.3 \%-0.5 \%)$. The survival rate of strain 194 was $96 \%$ after $1 \mathrm{~h}$ of exposure, $94 \%$-after $2 \mathrm{~h}$ and after $3 \mathrm{~h}-92 \%$. In the investigations on the influence of culture broth (lived lactococci with metabolites) of strain 194 on symptoms of chronic dermatitis on model mice CBRB-Rb $(8,17)$ 1Iem during two weeks of feeding (used daily as food additive and twice application on the skin of the back) showed the degree of ulceration and the square of damaged skin of the back of treated mice decreased by $21 \%$ after one week of culture application and the weight of the animals increased (by $4.5 \%$ ) to the end of experiment. Thus, we showed that use of 194 
strain as food additive clearly reduced the severity of dermatitis symptoms.

Growth in the medium containing glucose caused a decrease in the $\mathrm{pH}$ from 6.8 to 4.1 . The $\mathrm{pH}$ of the medium decreased to 4.8 over $9 \mathrm{~h}$ of the growth of strain 194, which was accompanied by an increase in the biomass (OD 540 from 0.30 to 1.58); in this process, the activity level increased to $3700 \mathrm{IU} / \mathrm{ml}$. The biomass accumulated gradually to $12 \mathrm{~h}$; nisin accumulated concurrently with the biomass, as demonstrated by an increase in the activity of the culture liquid: after $12 \mathrm{~h}$ the $\mathrm{pH}$ dropped to 4.1 , biomass increased to 1.66, and the level of antibiotic activity elevated 1.2fold $(4500 \mathrm{IU} / \mathrm{ml})$. After $12 \mathrm{~h}$ of incubation, the cells passed from the exponential growth phase to the stationary phase, which continued for $3 \mathrm{~h}$. After 15h, a further decrease in $\mathrm{pH}$, antibiotic activity, and optical density of the culture liquid were observed due to cell lysis. Acetic acid at $\mathrm{pH}$ above 4.5 shows a more pronounced inhibitory effect than lactic acid, and vice versa, at a $\mathrm{pH}$ below 4.0 is stronger antimicrobial activity observed in lactic acid $[16,17]$.

Table 4: Physicochemical properties of individual antibiotic substances, produced by Lactococcus lactis ssp. lactis 194.

\begin{tabular}{|c|c|c|c|c|}
\hline \multirow{2}{*}{ Properties } & \multicolumn{4}{|c|}{ Active components } \\
\hline & 194-A & 194-B & 194-C & Nisin A \\
\hline $\begin{array}{l}\text { Molecular mass, } \\
\text { (M+H)+, m/z, } \\
\text { (MALDI-MS) }\end{array}$ & 607.5 & 619.6 & 1995 & 3353 \\
\hline \multirow{2}{*}{$\begin{array}{l}\text { UV-VISspectrum, } \\
\lambda \text { max, nm, } \\
\text { (solvent) }\end{array}$} & 206.8 & 224.8 & 257 & 215 \\
\hline & $\left(\mathrm{C}_{2} \mathrm{H}_{5} \mathrm{OH}\right)$ & $\left(\mathrm{C}_{2} \mathrm{H}_{5} \mathrm{OH}\right)$ & $(\mathrm{C} 2 \mathrm{H} 5 \mathrm{OH})$ & (H2O) \\
\hline $\begin{array}{l}\mathrm{TLC}\left(\mathrm{SiO}_{2}\right), \mathrm{Rf} \text { in } \\
\text { system: }\end{array}$ & \multirow[t]{2}{*}{0.6} & \multirow[t]{2}{*}{0.42} & \multirow[t]{2}{*}{0} & \multirow[t]{2}{*}{0} \\
\hline $\mathrm{MeOH}-\mathrm{H}_{2} \mathrm{O}(96: 4)$ & & & & \\
\hline $\begin{array}{c}\text { paper } \\
\text { electrophoresis in } \\
\text { electrolytes } 30 \% \\
\text { AcOH: }\end{array}$ & \multirow[t]{2}{*}{0} & \multirow[t]{2}{*}{0} & \multirow[t]{2}{*}{7.6} & \multirow[t]{2}{*}{9,5} \\
\hline $\begin{array}{c}\mathrm{pH}=2.4,550 \mathrm{~B}, 2 \\
\mathrm{~h}, \mathrm{sm}\end{array}$ & & & & \\
\hline \multirow{2}{*}{$\begin{array}{l}\text { Antimicrobial } \\
\text { spectrum }\end{array}$} & $\begin{array}{c}\text { Gram+ } \\
\text { and gram- }\end{array}$ & Gram+ & Gram+ & Gram+ \\
\hline & $\begin{array}{l}\text { bacteria, } \\
\text { fungi }\end{array}$ & bacteria, & bacteria & bacteria \\
\hline
\end{tabular}

Bacteriocins are microbial proteins with antibiotic activity, which differ from antibiotics in the kinetics of the synthesis, being formed in parallel with the growth of producer microorganisms and DNA and protein synthesis [18]. As secondary metabolites, antibiotics are largely synthesized during the second (steadystate) phase of microorganism growth and subsequently, when the cells start to die. Our experiment, in which the dynamics of growth of the strains was studied in glucose containing medium, demonstrated that the increase in the antibiotic activity of the culture liquid paralleled the accumulation of the biomass of lactococci. The antibiotic complex isolated from strain194 appeared as a mixture of biologically active components which differed from nisin in Mass, Rf values, chemical nature and biological properties (Table 4).

Analytical HLPC, TLC, FAB-MS and FD-MMS methods were carried out to determine of structure of new complex. Component A had antifungal activity, and a low-molecular-weight $(\mathrm{M}=607.5 \mathrm{Da})$ and was hydrophobic. Antimicrobial substances A, in concordance with their UV-spectrum, molecular weight and spectrum of antimicrobial activity were identified as novel and absent in Berdy database BNPD. Studies of antimicrobial activities of the components isolated demonstrated that component A exhibited a broad-spectrum activity against the majority of gram-positive, gram-negative bacteria and mould. Component $\mathrm{B}$ was a minor fraction, and its biological activity was insignificant. These antibiotic complex isolated from strain194 may represent novel biologically active substances effected against potential pathogens.

It is revealed according to the results of studying the sensitivity to the antibiotics, these strains were sensitive to the antibiotics: ampicillin, erythromycin, tetracycline, lincomycin, to a lesser degree to aminoglucoside antibiotics-kanamycin, streptomycin, to the macro-lactam antibiotic-rifampicin, but it is resistant to neomycin and oleandomycin (Table 5).

Table 5: Sensitivity to antibiotics of isolated strains L.lactis subsp. lactis

\begin{tabular}{|c|c|c|c|c|c|c|c|c|c|}
\hline & \multirow{2}{*}{ Antibiotics } & mkg/ & \multicolumn{7}{|c|}{ Isolated strains } \\
\cline { 3 - 9 } & & $\mathbf{1 1 9}$ & $\mathbf{1 1 5}$ & $\mathbf{2 2 2}$ & $\mathbf{2 2 9}$ & $\mathbf{1 9 4}$ & $\mathbf{2 0 5}$ & $\mathbf{M} \mathbf{}$ \\
\cline { 3 - 9 } & & \multicolumn{7}{|c|}{ Diameter of inhibition zone, mm } \\
\hline Tetracycline & 30 & 36,5 & 35,0 & 35,0 & 33,6 & 28,5 & 30,4 & 35,5 \\
\hline Doxicycline & 10 & 32,0 & 32,5 & 32,0 & 34,0 & 27,5 & 29,8 & 34,0 \\
\hline Levomycetin & 30 & 25,2 & 26,5 & 23,0 & 32,0 & 25,5 & 23,6 & 26,0 \\
\hline Syzomycin & 10 & 19,0 & 17,0 & 18,0 & 16,5 & 10,0 & 14,2 & 17,5 \\
\hline Oleandomycin & 15 & 21,0 & 23,5 & 24,5 & 27,0 & 17,5 & 18,3 & 28,5 \\
\hline Riphampycin & 10 & 12,0 & 0 & 0 & 0 & 15,0 & 12,2 & 0 \\
\hline Neomycin & 30 & 0 & 0 & 14,0 & 0 & 12,0 & 0 & 0 \\
\hline Sreptomycin & 30 & 12,0 & 13,0 & 0 & 13,3 & 12,0 & 0 & 14,0 \\
\hline Kanamycin & 30 & 14,5 & 14,0 & 18,0 & 14,0 & 0 & 11,3 & 15,0 \\
\hline Ristomycin & 30 & 19,5 & 18,0 & 16,0 & 17,6 & 13,8 & 14,4 & 19,5 \\
\hline Methicyllin & 10 & 22,0 & 10,0 & 25,0 & 28,5 & 0 & 0 & 16,0 \\
\hline Benzylpenicillin & 10 & 22,6 & 26,6 & 24,5 & 27,0 & 0,0 & 18,5 & 26,5 \\
\hline Karbinicillin & 10 & 32,0 & 30,6 & 32,0 & 29,5 & 12,0 & 21,1 & 30,5 \\
\hline Oxaciklin & 10 & 21,0 & 22,0 & 19,0 & 18,5 & 10,0 & 13,6 & 17,5 \\
\hline Ampicillin & 10 & 29,0 & 28,0 & 32,0 & 32,6 & 20,0 & 23,4 & 26,5 \\
\hline Cephalotin & 30 & 30,5 & 29,0 & 29,0 & 30,5 & 27,0 & 26,8 & 31,0 \\
\hline Cephalexin & 30 & 18,0 & 24,0 & 20,0 & 28,0 & 13,0 & 15,7 & 28,0 \\
\hline
\end{tabular}

We detected effect novel culture on symptoms of dermatitis in mouse models. Old CBRB mice under conventional (non-SPF) conditions were shown to mimic some characteristics of human 
chronic dermatitis spontaneously: impetigo, ectima, and some others. The aim of this study was to investigate the influence of culture broth (KB) of Lactococcus lactis subsp. lactis strain 194$\mathrm{K}$ on symptoms of chronic dermatitis in CBRB male mice during two weeks. KB was used daily as food additive and twice 0-0as application on the skin of the back. The following parameters and symptoms of dermatitis were monitored: the level of skin ulceration and alopecia, the square of damaged skin of the back, and the weight of the animals. The degree of ulceration and the square of damaged skin of the back of treated mice decreased after one week of KB application, but later both parameters became equal to the corresponding control parameter values. The extent of alopecia of treated animals remained decreased during the whole experiment as compared to alopecia in the control group. The weight of treated animals increased to the end of experiment. Thus, we showed that use of 194-K strain as food additive clearly reduced the severity of dermatitis symptoms, but timing, dosages, and scheme of KB application should be optimized. Thus, the unique properties of these strains, stability to the action of bili acids, the wide spectrum of bactericidal and fungicidal action to the pathogens, the absence of toxicity make it possible to recommend it for creating the probiotic cultures.

\section{Conclusion}

Screening for the effective strains from raw milk of Buryatia in accordance with its geographical and natural characteristics of this North Asiatic region of lake Baikal, revealed the isolation of new lactococci cultures. This region includes a wide variety of climatic and ecological niches, thus creating conditions for a variety of new LAB with their unique properties. Thus, our studies are of great scientific and practical interest for the operation. On the basis of morphological, cultural, physiological, biochemical properties and accordingly to $16 \mathrm{~S}$ rRNA gene sequence of isolates they were identified as Lactococcus lactis subsp. lactis. The most promising strain was 194 (accession number in Gen Bank is DQ255954), which synthesized antibiotic complex with a wide spectrum of antimicrobial activity, effective against pathogens. This strain have "GRAS" status. Thus, the properties of these strains with the wide spectrum of bactericidal and fungicidal action to the pathogens, the absence of toxicity and medical effect in a mouse model of chronic dermatitis enable to recommend the strain L. lactis ssp. lactis 194 for using as probiotic culture or as potential perspective bio-preservative for preventing fungal spoilage of foodstuffs and edible raw materials with probiotic effect. This strain has "GRAS" status, potential applications of culture broth of these strains in various food fermentations, allow recommend it as potential perspective bio-preservatives for preventing fungal spoilage of foodstuffs and edible raw materials.

\section{References}

1. Fuller R, Gibson GR (1998) Probiotics and prebiotics: microflora management for improved gut health. Clin Microbiol Infect 4: 477-480.

2. Holzapfel WH, Haberer P, Geisen R (2001) Taxonomy and important features of probiotic microorganisms in food and nutrition. Am J Clin Nutr 73(2 Suppl 1): 365-373.

3. Madden JA, Hunter JO (2002) A review of the role of the gut microflora in irritable bowel syndrome and the effects of probiotics. Br J Nutr 88 Suppl 1: S67-S72.

4. European Parliament and Council. Regulation (EC) 248/97 of the European Parliament and of the Council of 27 Jan 1997 concerning novel foods and novel food ingredients.

5. Stoianova LG, Ustiugova EA, Netrusov AI (2012) Antibacterial metabolites of lactic acid bacteria: their diversity and properties. Prikl Biokhim Mikrobiol 48(3): 259-275.

6. Bernbom N, Licht TR, Brogren CH, Jelle B, Johansen AH, et al. (2006) Effects of Lactococcus lactis on composition of intestinal microbiota: Role of nisin. Appl Environ Microbiol 72(1): 239-244.

7. Nes IF, Diep DB, Holo H (2007) Bacteriocin diversity in Streptococcus and Enterococcus. J Bacteriol 189(4): 1189-1198.

8. Yildirim Z, Yildirim M, Johnson MG (2004) Mode of action of lactococcin R produced by Lactococcus lactis R. Nahrung 48: 145-148.

9. Lowe D, Arendt E (2004) Lactic acid bacteria in malting and brewing with their relationships to antifungal activity. Micotoxins and gushing: A review. J Inst Brew 110: 163-180.

10. Ryan MP, Meaney WJ, Ross RP, Hill C (1998) Evaluation of lacticin 3147 and a teat seal containing this bacteriocin for inhibition of mastitis pathogens. Appl. Environ Microbiol 64(6): 2287-2290.

11. Hayashi A, Kimura M, Nakamura Y, Yasui HJ (2009) Anti-atopic dermatitis effects and the mechanism of lactic acid bacteria isolated from Mongolian fermented milk. Dairy Res 76(2): 158-164.

12. Iannitti T, Palmieri B (2010) Therapeutical use of probiotic formulations in clinical practice. Clin Nutr 29: 701-725.

13. Ludwig W, Schleifer KH, Whitman WB Revised road map to the phylum Firmicutes. Bergey's Manual of Systematic Bacteriology, The Firmicutes. NewYork, USA.

14. Stoianova LG, Egorov NS, Fedorova GB, Katrukha GS, Netrusov AI (2007) A comparison of the properties of bacteriocins formed by Lactococcus lactis sub sp. lactis strains of diverse origin. Prikl Biokhim Mikrobiol 43: 677-684.

15. Mechnikov II, Kowalewski OA (1956) Chosen works. Moscow. State educational and pedagogical publishing house of the Ministry of Public Education of Russia.

16. Nurushev MZh, Stoianova LG, (2011) About the project of creation of a new functional product like koumiss on the basis of cow's milk, integral and powder. The bulletin of the Euroasian National University of L. N. Gumilev, N4 (83) of 2011, pp. 181-188.

17. Holzapfel WH, Haberer P, Geisen R (2001) Taxonomy and important features of probiotic microorganisms in food and nutrition. Am J Clin Nutr 73(2 Suppl): 365-373.

18. Diep DB, Nes IF, (2002) Ribosomally synthesized antibacterial peptides in Gram positive bacteria. Current Drug Targets 3(2): 107-122. 


\section{Your next submission with Juniper Publishers} will reach you the below assets

- Quality Editorial service

- Swift Peer Review

- Reprints availability

- E-prints Service

- Manuscript Podcast for convenient understanding

- Global attainment for your research

- Manuscript accessibility in different formats

( Pdf, E-pub, Full Text, Audio)

- Unceasing customer service

Track the below URL for one-step submission https://juniperpublishers.com/online-submission.php 